\title{
Exploring Gendered Understandings of Peace in Delta State
}

\author{
Ceren Bulduk, Joy Onyesoh and Mimidoo Achakpa
}

\begin{abstract}
In this chapter we draw a picture of alternative visions of peace from the standpoint of individuals affected by violent conflict and engaged in peacebuilding in Delta State, Nigeria. Drawing on interviews conducted with NGO s, a community group, and vigilantes, we identify multiple and sometimes contradictory meanings. We discuss these against theorisations of peace in the academic literature and find resonances that allow us to bring community meanings of peace into conversation with the literature. From our interviews, we identify and discuss an understanding of positive peace that requires economic development. We also identify a vision of harmonious living that involves overcoming negative emotions, and draw on feminist literature to connect this vision to the concepts of maternal thinking and building relations of care. Finally, we identify a commitment to peace as inclusive of women, yet note that the extent and form of inclusion is contested among different actors. Assessing these understandings of peace through a gender lens, we argue that gender logics inform these multiple meanings.
\end{abstract}

Introduction

Critical scholars have brought to light the importance of 'the everyday' in peacebuilding, highlighting the agency of local populations and seeking to valorise their voices in constructing peace (Mac Ginty, 2014; Mac Ginty and Richmond, 2013). A focus on the everyday underlines the ethical and analytical urgency of bringing to light the understandings and experiences of those who have lived through violent conflict and are engaged in peacebuilding. It also reveals the power of individual and community practices in framing and constituting peace on the ground. In this chapter, we seek to make visible understandings of peace among communities in Delta State, Nigeria, a state rent by lethal violence, but one that also is the site of a diverse range of peacebuilding initiatives. What visions of peace do peacebuilding agents put forward? 
Violence in the Niger delta (which encompasses Bayelsa, Rivers, and Delta States) is typically associated with oil exploitation. However, such violence also has a long history and predates the discovery of oil in 1957. Intracommunal, intercommunal, interethnic, political, and criminal violence have undergirded the violence of rebel groups, its different types merging into one another and shifting over time (Ebiede, 2017). Despite the 2009 amnesty agreement with rebel groups and the implementation of a programme of disarmament, demobilisation and reconstruction, there were over one thousand recorded deaths in the Niger delta in 2019, and Delta State was one of the most volatile states based on the number of reported fatalities (PIND, 202O).

Motivations for conflict and violence in the state are diverse and include land disputes, disagreements with oil exploration companies over revenue or compensations, cult clashes, electoral violence, and sexual and gender-based violence. For instance, electoral violence is widespread in the region as political leaders recruit youths and arm them to intimidate the electorate and electoral officials in order to manipulate election results in their favour. After the elections, groups of armed youths often turn into militant organisations, leading to clashes of greater violence. Another trigger is the never-ending battles between rival gangs and cult groups for the control of the creeks, many of which are routes for oil bunkering, or oil theft. Bodo, Gimah and Seomoni $(2020)$ argue that this is a booming and profitable business, which consists of a multitude of different actors including the local militant groups in the creeks, commodity traders, and military personnel. Likewise, communal violence driven by tensions over land and boundary disputes is a widespread cause of fatalities (PIND, 2020). The violence in Delta State has impeded development, entrenched widespread poverty, and impacted the lives of thousands of people. Showcasing these people's visions for a peaceful future highlights their status not only as victims but also as agents in building peace in their communities.

In this chapter, we identify meanings of peace in Delta State from the interviews we conducted with non-governmental organisations (NGOS) and community and vigilante groups. Committed to a feminist epistemology, we seek to understand peace from a bottom-up perspective, bringing to the fore the standpoint of the individuals concerned. Drawing a picture of alternative visions of peace, we discuss different understandings against the rich scholarly body of theorisations of peace in the academic literature. We show that visions of peace cannot be thought of as uniform, but include multiple imaginaries that may clash with one another. We reveal the ways in which these multiple meanings/imaginaries of peace are gendered by studying them through the lens of gender logics discussed in the introduction to this thematic volume. In 
particular, we show that gender structures these visions-that is, they reproduce gendered roles as hierarchically arranged dichotomies, and construct binary gender identities, propelling performances of sometimes (but not always) stereotypical femininity and masculinity.

In the following, we first introduce theoretical literature around themes and concepts that emerged from the interviews as qualities of peace. This includes the discussion in the literature of peace as an absence of direct and structural violence that also requires economic development, of involving relationality and relations of care, and of requiring gender inclusivity. We then bring this literature into conversation with insights from our interviewees about economic development, harmonious living and relations of care, and peace as a state of being that is inclusive of women. We show that gendered logics inform these visions of peace, circumscribing the ways in which women and their issues are included or excluded, the divisions of labour reproduced, and the identities constructed.

The study was conducted in the South Warri and Uvwie Local Government Areas of Delta State in December 2018. The research team included two national coordinators and three local researchers. The team held several meetings with different groups and organisations, collecting data through focus group discussions (FGD s) and in-depth interviews following an agreed-upon guide. In this chapter, we use the interviews that the team conducted with the civil society organisations Gender Justice, Community Peace and Development Initiative, One Love Civil Society Organisation, Ideal Women Advancement Initiative, Value Rebirth and Empowerment Initiative, The Right to Education Empowerment Centre for Social Change, Women in Peacebuilding NetworkNigeria, and Women Peace and Security Network. We also include in our analysis the FGD s that were conducted with the Okukokor Vigilante Group ${ }^{1}$ and the Ekpan Community Stakeholders Group, the latter being a coalition of the various interest groups in the Ekpan community. The organisations whose interests are represented in the Ekpan Community Stakeholders Group include Ekpan Women Peace Initiative, Ekpan Integrity, Community Liaison Officers, and Community Relations Committee. The discussions and interviews were recorded and transcribed for coding and for ease of analysis.

1 Vigilante groups emerged as a response to theft and robbery and have a long history in Nigeria. See a more detailed analysis of the proliferation of vigilantism and politics of vigilante groups in Prattern (2008). 
There is a large body of interdisciplinary literature seeking to define and problematise the notion of peace. Given our bottom-up approach to the topic, we discuss in this section theorisations of peace that speak to the main themes identified in our interviews. These theorisations problematise the idea that peace means an absence of physical violence, evoke a 'positive peace' that also requires economic development, and bring to bear feminist understandings of care as a form of peacebuilding and the need for gender inclusivity.

\subsection{Positive Peace and Peace Economies}

Notwithstanding the disagreements over the qualities of peace in policy and academic debates, one of the virtually undisputed attributes of peace is the absence of violence. There are, however, important divergences in the perceptions of what is considered violence and what types of violence must be eliminated for peace to emerge. A narrow definition focuses on physical injuries and death. In contrast, those who champion the broader definition of violence argue that injuries of other kinds are no less painful. For Galtung, for example, 'violence is present when human beings are being influenced so that their actual somatic and mental realizations are below their potential realizations' (Galtung, 1969, 168). He distinguishes between direct violence (where the instigation of an act of violence can be traced to a person or persons) and structural violence (where the violence is built into structures and manifests itself as unequal life chances). Even though peace is understood broadly as freedom from violence, whether this is the absence of direct violence and war or the absence of structural violence in the form of social injustices and oppressions, constitutes a cornerstone of academic debates. These distinctions imply two different types of peace. While negative peace is the absence of direct forms of violence, positive peace entails the absence of any form of structural violence and 'the integration of human society' (Galtung, 1964, 2).

Those who champion the idea of positive peace pay attention to human agency, individual needs, and their fulfilment, and aim to deliver peace through the affective, emotional, logical and experiential elements of everyday life (Mitchell, 2011). In these arguments, peace is framed as a desire, aspiration, and fulfilment. It is also conceived as a profoundly affective concept, including emotional elements of everyday life such as wellness and flourishing. Lederach 
(2007), for instance, builds his notion of 'sustainable peace' on the metaphors of health and wellness, arguing that sustainable peace is like the immune system in the body or a healthy ecosystem in the environment', whose goal is to create 'healthy, generative social interaction'. Likewise, for Hugh Miall (2007), the idea of positive peace relates to the goal of human flourishing; the idea of self-realisation of human beings rather than mere survival. Mitchell (2011) shows that fulfilment consists of social harmony, economic prosperity and individual betterment, as well as the ability for humans to develop and use their capacities for creativity, service and enjoyment. Positive peace is thus tied up with the idea of 'cultivating and altering the quality of life by means of the specific qualities of the everyday-including caring, communication and interaction' (Mitchell, 2011, 1635).

A major element of human flourishing in a positive peace is economic wealth, and the question of how to promote such wealth is a major point of contention in the literature. Many scholars turn their attention to economic causes to explain the puzzle of violent conflict, studying a range of different economic variables. This stream of thought includes the theories on the 'resource curse', that is, the argument that countries with abundant natural resources are more prone to violent conflict, and the theories on greed, that is, the idea that profitable opportunities for rebel groups are a cause of violent conflict (Collier and Hoeffler, 2004; Ross, 1999). Such scholars imply that economic causes play a more prominent role in fuelling violent conflict than 'grievances'; that is, political differences, inequalities, or ethnic divisions. Paul Collier (2009), for example, states that

ethnic tensions and ancient political feuds are not starting civil wars around the world [...] economic forces-such as entrenched poverty and the trade in natural resources-are the true culprits. The solution? Curb rebel financing, jump-start economic growth in vulnerable regions, and provide a robust military presence in nations emerging from conflict.

As exemplified by Collier, and explained by Rigual (2018) in detail, the conflict analysis of economics scholars suggests that one of the pathways to peace is economic development as conflict is understood to be deeply rooted in economic causes. In this literature, development is mainly expected to happen through neo-liberal economic policies that aim to liberalise domestic markets, promote foreign direct investments (FDI s) and introduce structural adjustment programmes championed by international financial institutions (IFI s). 
Though this approach has remained the main paradigm in the policy realm, it has led to heated discussions, particularly within academic circles. ${ }^{2}$

Many scholars have problematised the appropriateness of neo-liberal economic policies in post-conflict countries, arguing that they might have adverse effects for politics and everyday lives in post-conflict societies. Ahearne (2009), for instance, argues that the economic reforms initiated by IFIs and donors following the civil war in Sierra Leone oversimplified the relationship between poverty and conflict and that between growth and peace. Even though Sierra Leone enjoyed reasonable growth after conflict, this growth did not 'trickle down' to the poor and the marginalised, and food security, unemployment and poverty continue to be problems for Sierra Leoneans. Similarly, even though FDI is deemed essential for the development of post-conflict countries, contributing to the creation of new employment opportunities and bringing in new technologies, many scholars point out the potential negative consequences of FDIS in post-conflict countries, including the aggravation of conflicts over access to land, or to jobs or revenues generated by companies. Paczynska (2016), for instance, shows that the FDI s made in post-conflict Liberia were mostly channelled into palm oil, forestry and rubber and exacerbated political tensions and protests. She argues that the post-conflict economic strategies introduced in Liberia recreated the pre-war economy, when a small political elite and foreign companies benefited from natural resource wealth by marginalising the majority of Liberians. These issues have guided scholars to make distinctions between war/peace economies and positive/ negative peace economies.

Peterson (2014) argues that the aim of all economic reforms proposed by guiding actors in post-conflict countries is to transform what is called the 'war economy'; that is, the structures of economic relations that prolong or sustain violence. Peace economies, on the other hand, are constituted by economic relationships that neither benefit from nor have a causal relationship with physical, organised political violence. Peterson classifies peace economies as either negative or positive peace economies. While a negative peace economy prioritises stability and an absence of immediate physical violence as a result of economic incentives, a positive peace economy is more transformative and aims to abolish not only physical violence, but also other forms of injustice, such as discrimination, fear, or intimidation. Feminist understandings of

2 Even though the liberal approach has been somewhat moderated in recent years having been given a 'social face' or even a 'feminist face', the commitment to orthodox economics remains. See, for example, Prügl (2016). 
peace are comparable to Peterson's positive peace economy as it aspires to the economic and social empowerment of women and other marginalised groups.

\subsection{Relationality and Relations of Care}

While both struggles over justice and an absence of violence have remained important aspects of academic debates around the nature of peace, feminist scholars have expanded the discussion by framing peace not only as an issue of social justice and human flourishing, but as a state of being that is tied to relationality and relations of care. The conception of feminist peace that arises from the arguments of second wave feminists is centred on an ethic of caring; 'of knowing, feeling, and acting in the interests of another' (Forcey, 1991, 334). Scholars promoting such an ethic direct their attention to maternal practices of caregiving and nurturing, which give rise to an ethic of care that is characterised by receptivity, relatedness, connectedness, feelings, empathy and caring (Forcey, 1991). Sara Ruddick (1989) analyses the principles of maternal practice through the lens of the ideals of non-violence, which she defines as renunciation, resistance, reconciliation and peacekeeping. Ruddick argues that mothers reject violence and are committed to non-violent techniques even when they are the more powerful ones in their relationship with their children-which she calls the 'nonviolence of the powerful' (Ruddick, 1989, 166).She contends that mothers choose methods such as persuasion, self-suffering, negotiation, bribery or the invocation of authority. Such methods of renunciation of violence also include training the children: 'a mother has to train children not to stamp on the baby, throw a rock at the head, push a toddler in the river, or squirt insecticide in an enemy's face' (172). Ruddick argues that mothers who are guided by the ideals of non-violence train their children to prefer justice over tyranny and exploitation. For Ruddick, maternal practices are inherently dependent on relationships and an ethic of care. She argues, "The peacemaker asks of herself and those she cares for not what they can afford to give up, but what they can give, not how they can be left alone, but that they can do together' (181). That is why for Ruddick non-violent mothers and their maternal practices offer an image of peace as an active connectedness.

Individuals are not primarily centers of dominating and defensive activity trying to achieve a stable autonomy in threatening hierarchies of strength, although this does describe some individuals and some moments in most lives. They are also and equally centers of care, actively desiring other selves to persist in their own lively being, judging their own well-being in terms of their capacity for a love that 'struggles towards definition'.

RUDDICK, 1989, 183 
At the centre of such practices of care are relationships that are built on empathy, love, understanding and dialogue. These kinds of caring relations/encounters, as Noddings (2008) argues, involve the carer and the cared-for, who both contribute to the relationship. While the carer is attentive to the needs of the cared-for, the cared-for responds in a way that acknowledges the effort of the carer. For Noddings, key to caring relations is dialogue, as it is through dialogue that expressed needs, motives and interests are identified. For this reason, Noddings argues that dialogue is central to every human interaction, and especially to caring ones. Such an understanding of relationships of care is also acknowledged outside feminist scholarship. For Allan (2006), for instance, global care is the highest achievable level of peace and involves an affective dimension because of its focus on caring for others and human social intercourse. Allan argues that principles of justice are crucial for making the world a better place and that care needs to include general conceptions of justice. However, as the humane aspects of consideration, sympathy and compassion for others lead the principles of an ethic of care, peace grounded in these principles goes beyond justice. It goes beyond the right to be treated equally as the focus is on treating others humanely. This kind of ethic is committed to the notion of non-violence with the aspiration that no one should be hurt. In the context of peacebuilding, Vaittinen et al. (2019) show that everyday forms of care that are practiced by men and women alike play a crucial role in creating trust and peaceful transformations of conflict.

\subsection{Gender Inclusivity}

At the core of feminist visions of peace is the idea of including all in creating peace, and of the eradication of multiple sources of oppression based on social identities such as gender, ethnicity or race. Duncanson (2016) argues that such an intersectionally inclusive view of peace is necessary as genuine peace requires the empowerment of individuals and communities to realise their own security.

Feminist scholars have long emphasised the gendered impacts of violent conflicts and revealed the importance of women's equal and meaningful participation in peace processes. They have shown that in situations of violent conflict women are disproportionately affected by widespread human rights violations including but not limited to sexual and gender-based violence. ${ }^{3}$ Given the disproportionate gendered impacts of conflict on women, True and

3 Even though we do not aim to detail the feminist theorisations of sexual violence in armed conflict in this chapter, we think that it is important to highlight the richness of these discussions. See, for example, the different strands of feminist thought on sexual 
Riveros-Morales (2019) argue that women's participation in peace processes is imperative. In spite of the introduction of the women, peace and security agenda more than two decades ago with the landmark United Nations Security Council Resolution 1325, feminist scholars have shown that women have been excluded from peace processes or that their influence remains limited when they are present. These scholars have also shown that the inclusion of women in peace processes is crucial not only in confronting gender-based subordinations, but also for the conclusion of peace talks and the implementation of peace agreements (Paffenholz et al., 2016).

Even though women's inclusion in such processes is perceived as immensely valuable for peace, many feminist scholars are wary of framing women and gender equality as a means of achieving peace. Duncanson (2016), for instance, criticises Hudson et al'.s (2012) argument, presented in their Sex and World Peace, that gender equality is necessary for peace, claiming that such an argument frames women's rights as a means to an end and falls into the trap of instrumentalising women. Instead, she suggests an understanding of gender equality as mutually constitutive with peace and emphasises the significance of framing women's empowerment as a goal in itself.

\section{3}

\section{Understanding the Gendered Meanings of Peace in Delta State}

The NGOs and community and vigilante groups we interviewed in Delta described peace in a multitude of ways. Yet there were also commonalities. The qualities and concepts interviewees referred to include an understanding of positive peace encompassing economic development; harmonious living and relations of care; and women's inclusion. In this section, we further explore the meanings of these concepts and qualities from the standpoint of our interviewees. We also put these understandings into dialogue with the discussions introduced in the theoretical chapter (conceptualisations of peace in the literature), which speak to the interviewees' conceptualisations of peace in Delta. The case of Delta not only reveals the multiple properties that are

violence: Reid-Cunningham (2008), Seifert (1996), Costantino (2012), Eriksson Baaz and Stern (2009; 2013), Meger (2011; 2016), Cohen (2013; 2016; 2017), and Wood (2006; 2009; 2018). It is also crucial to note the violence men and gender-non-conforming individuals experience in the context of armed conflict. Across the world, many armed groups in conflict-affected contexts have directed violence against people due to their sexual orientation and/or gender identity. See Daigle and Myrttinen (2018), Serrano-Amaya (2018) and Drumond (2018). 
attached to peace by different organisations/groups, it also shows the structuring and identity logics of gender that inform such meanings.

\subsection{A Positive Peace Economy}

A first meaning that emerged from the interviews is of peace as the absence of both direct and structural violence. Even though many interviewees emphasised the absence of overt forms of violence as central to the realisation of peace, they understood violence more broadly. Many considered social, political and economic inequalities as threats and regarded the eradication of these structures as fundamental to achieving peace. Peace then becomes a matter of social justice, fairness and equality, as one of our NGO interviewees formulated the issue:

To be in a situation of peace: when you look at a situation where there is justice for all. When I say justice, I am talking of fairness [...] where there is fairness, where there is quality of life, where the socioeconomic situation of the community or the society is fully shared among the dwellers, male or female...

Community Peace Development Initiative, interview, 2018

Peace, justice and fairness seem to belong together in this formulation; but so do 'the socioeconomic situation of the community' and 'quality of life'. Justice and fairness are positioned to generate a high quality of life. Indeed, what the peace and conflict literature refers to as economic development emerged, in many of our interviews, as key to achieving social justice and thus as a prerequisite for peace. In the words of one research participant, 'those small issues like employment and development issues within the community make peace come' (Ekpan Community Stakeholders Group, interview, 2018). Practically, this meant the eradication of poverty through employment and income generation activities, as mentioned by many of our interviewees. The 'small issues' of economics emerged as intricately enmeshed with the large issue of peace.

Our interviewees also emphasised that the principles of equality and fairness needed to encompass gender relations. This theme emerged especially strongly among our NGO interviewees: 'Our peacebuilding [work] is on equity. What is good for men is good for women; what is good for you is good for me. We try to entrench this culture because denial is a trigger of conflict' (Value Rebirth and Empowerment Initiative, interview, 2018).

Emphasising gender equity, in explaining the initiative's socioeconomic justice and governance focused peacebuilding work this interviewee's understanding resonates with the positive peace economy advanced by Peterson 
(2014), as reviewed above, which includes transformations of inequalities and injustices, including those related to the governance of natural resources. Women's NGO s in particular emphasised the issue of gender discrimination in land ownership and mentioned their involvement in land disputes.

However, such gendered discriminations did not appear in many of the interviewees' accounts of peace or in initiatives on peacebuilding. When it came to the equal distribution of resources and jobs, meanwhile, some of our interviewees gave preference to men. This preference was particularly visible in the interviews with the stakeholders from Ekpan community. For instance, one interviewee from the Ekpan Community Stakeholders Group mentioned the insufficient employment opportunities created by private oil companies:

And in my own area $[. .$.$] we have a lot of companies there and they are$ not really helping us to make peace come to stay because they are not helping our boys in terms of employment ... it is part of what makes our boys misbehave. And I believe that if they help us to give employment to our boys, $[\ldots]$ peace will come, as in peace will come to stay.

Ekpan Community Stakeholders Group, interview, 2018

Here the structuring logic of gender asserted itself to help constitute the meaning of peace. Having constructed men, and male youth in particular, as those with an inclination to resort to violence, a gendered logic leads to a prioritising of employment for men. Men's lack of income and employment opportunities comes to frame discussions around peace, because economic injustice against them is seen as connected to the perpetuation of violence. In contrast to the first NGO we quote in this section, this understanding portrays a more restricted understanding of peace in terms of 'socioeconomic situation'. When put into dialogue with the literature we reviewed, we find that the kind of economic peace imagined by this interviewee neither takes into account the gender dimensions of structural violence nor prioritises the economic and social empowerment of women. As a result, even though some organisations emphasised the economic empowerment of women and introduced initiatives in this regard, the qualities that are at the heart of a feminist peace economy are not represented in some others' understandings of peace in Delta.

\section{2 'Harmonious Living' and Relations of Care}

Our interviewees considered peace not only as related to the issue of economic justice, but also as a quality of social relationships. A widely shared framing of peace that emerges from the interviews is the idea of 'harmonious living', which highlights the affective and relational qualities of peace. Many 
interviewees approached conflict as endemic in social life and thus as something that needed to be managed. As a representative of one NGO suggested, 'conflict is not positive or negative, it is the handling of the conflict that brings peace' (One Love, interview, 2018). And many of our interviewees emphasised that maintaining social ties was crucial to managing conflict. The idea of harmonious living as a product of human interactions emerges as a key element in this. It carries resemblances to what feminist scholars would call relations of care. Thus, relationality is an essential element of peace as harmonious living: 'Relationship; when there is this, there will be no violence' (One Love, interview 2018).

In the narratives of our interviewees, such relationships are built on a range of affective qualities. To begin with, there are negative emotions, such as fear and distrust, that need to be overcome in order to found peaceful relationships: 'We have peace when each party clearly understands the interests of the other side with respect to accommodating their views. There will be absence of fear and distrust' (Okukokor Vigilante Group, interview, 2018).

Eliminating fear and distrust makes it possible to understand the interests of others and accommodate them. Conversely, understanding and respecting others prevents fear and distrust. A stakeholder group participant agreed with this interpretation, adding the need for tolerance: 'I think it is still brought down to understanding, tolerance, tolerating one another and harmonious living together; that is peace' (Ekpan Community Stakeholders Group, interview, 2018).

Respect and tolerance thus brought about harmonious living or peace. They also make it possible to overcome 'rancour or bitterness' and thus to achieve unity: 'Peace is when people live together harmoniously without rancour or bitterness towards one another [...] first thing that will make us to have that peace is to unite and understand ourselves. If we refuse to unite and understand ourselves, peace will never come' (Ekpan Community Stakeholders Group, interview, 2018).

Overcoming negative emotions and embracing understanding and respect thus is not something that entails individualised feelings, it is central to building community, unity. Harmonious living thus is built on social ties.

Arguably this discussion connects to theoretical understandings of relations of care. It recalls Noddings's (2008) arguments, discussed earlier, about the centrality of dialogue to caring human relations. Dialogue makes it possible to express needs, identify potentially clashing interests, and understand them 'with respect to accommodating their view', as expressed by the interviewee above. Our interviewees also understood, though, that this needed the eradication of emotions such as fear and distrust, that dialogue and understanding 
needed relations based on tolerance and trust. Thus our interviewees constructed peace not only as something more than justice for all, but also as profoundly reliant on the presence of what feminist theorists have called caring relations.

Caring relations also surfaced in another context-in discussions about mothers as peacebuilders. The figure of the powerful mother is familiar from other African literature on peacebuilding (Prasch, 2015; Oyewumi, 2003); in Delta, it featured in the way relations of care between a mother and her children were perceived as playing a central role in assuring peace. In the accounts of many of the NGO s and the community group interviewed, women are produced as mothers who are responsible for educating their children and can thus ensure peace in the community. 'Gender is a social construct but in reality, women are central, care and home keepers. They are mothers and they play a major role in peacebuilding. A good woman can educate her children to play an active role in peacebuilding' (One Love, interview, 2018).

Whereas it is, in the matter just quoted, a mother's care and education that enables peacebuilding, another interviewee highlighted the mother's power to control:

A mother can really control the child in the home and the mother can control peace at home and within the community. Because the mother can control the child from home as a means of teaching the child [...] that little boy will grow up to be the best father. That is one of the works of mothers.

Gender Justice, interview, 2018

The particular relationship between mother and child is what enables both care and control. It is the unique requirement of managing this power relationship that motivated care theorists, such as Ruddick, to develop their arguments about maternal practices of non-violence. Like our interviewees, Ruddick emphasises mothers' power in the training of children to counteract violence. And like Ruddick, our interviewees also emphasise that this is not simply a matter of ties between mother and child, but has implications for the community: women can educate their children to 'play an active role in peacebuilding' and the mother can 'control peace at home and within the community'. Thus, they show that the human relations that are central to the building of peace not only include the relations between adversaries or relations outside the context of the family, but also relations between mothers and their children. In other words, relations of care go beyond developing mutual understandings, tolerance, or trust between parties who have conflicting interests; they 
also involve mothers' maternal practices of renouncing violence, expressed through the training of their children. Peace relies on relationality and care at the level of the family and the extension of such relations to the community.

As has been shown in the literature, gendered logics can re/assert themselves in visions of peace. The risk is that a rigid gender division of labour is reproduced, and we see this reflected in the statement of the interviewee quoted above in the sense that 'gender is a social construct but in reality, women are $[\ldots]$ care and home keepers'. This seems to suggest that gender is not malleable, that women are always already or potentially mothers 'and home keepers', and that non-violence is quasi-innate in these roles. Yet the reference to 'a good woman' moderates this suggestion, implying that mothering for peace may require skills and competence, and perhaps involve a process of learning. Indeed, a number of NGO s interviewed targeted women as mothers in their initiatives with the aim of encouraging maternal practices of non-violence and increasing the authority of mothers over their children and in the peacebuilding training of children. In doing so, these organisations also drew on gender, producing performances of the 'good woman' and reproducing traditional gender identities. But for Ruddick, mothering is not attached to women; non-violence emerges from maternal practices and thinking, and everybody can embrace these, regardless of whether they are mothers or not. In the words of the interviewees, meanwhile, motherhood is reserved for women.

\subsection{Women's Inclusion}

The different sets of properties attributed to peace in Delta in the interviews also lead to various understandings of peace related to the issue of women's inclusion. On the one hand, many of the interviewees underlined the significance of the political inclusion of women in the structures of governance and in peacebuilding processes. In these accounts, the exclusion of women was deemed 'a threat to peace', and the eradication of structures of subordination was regarded as crucial to ensuring the peace in Delta. Women's organisations in particular emphasised the importance of developing women's political potential, improving their access to income, and in some cases training men in leadership positions to help combat prejudices against women as agents of peace. On the other hand, some NGOs instrumentalised women's political participation in the building of peace, forgoing the idea that women's empowerment may be a goal in and of itself. For instance, an NGO staff member mentioned, with regard to the training they provide for male community leaders to increase the participation of women: 'If a woman has an answer to the prevention of conflict, we are more interested in the overall goals and in 
the overall peaceful coexistence (Value Rebirth and Empowerment Initiative, interview, 2018). The interviewee maintained that 'who brought in the result' is not important.

The same interviewee concluded that what matters for the organisation is the 'competence' of an individual, irrespective of gender. That is, if a man is more 'competent' in a particular area, 'he will take the lead', and the same also applies to women. The empowerment of women thus becomes secondary; the goal is peace and women's participation is a means to get there. The same interviewee also mentioned that bringing women peacebuilders into certain communities may be considered insensitive. Many other interviewees similarly mentioned the impact of community restrictions on the gender-division of their peacebuilding work and framed the inclusion of women as a concern that should be sensitive to community dynamics.

But some even questioned whether women can be a means of achieving peace, and justified the limited role of women in political and peacebuilding processes. For instance, one of the vigilante groups labelled women as 'weak' and unable to help the group in supporting their operations against crime. At the same time, group members held women themselves responsible for not showing an interest in joining the group.

Women are not part of the vigilante [group] because it is a very stressful and dangerous job. Women cannot fight criminals [...] No one stops anyone from joining. Since the inception of the vigilante group, no woman has come to join the group. I believe women do not have the power or self-will to join the vigilante group.

Okukokor Vigilante Group, interview, 2018

Women's roles are, instead, framed as limited to mediating conflicts between couples and among women. The structuring logics of gender in this case assigned the 'appropriate' roles for women in achieving 'harmony'. The rejection of inclusivity and the framing of women as 'weak' reproduced gender divisions of labour and led to the exclusion of women from certain types of peacebuilding efforts that were perceived as masculine.

\section{4}

\section{Conclusion}

What are the visions for peace of peacebuilders that work in a context of violent conflict? Our analysis of such visions in Delta State uncovers multiple and sometimes contradictory, meanings. These include an understanding of peace 
as an absence of both direct and indirect violence, encompassing in particular economic development. They also include the notion of harmonious living, which involves overcoming negative emotions and building relations of care. We have shown that these visions can be brought into conversation with the academic literature. They connect to notions of positive peace put forward by Galtung, and they emphasise the economic basis of peace and the need for economies to be equitable, as suggested in Peterson's notion of a peace economy. They also connect to theorisations by Lederach (2007) and Miall (2007) of peace as including human flourishing experienced in everyday life, which our interviewees characterised as 'harmonious living' and achieving 'quality of life'. We show that this understanding resonates with ideas put forward in feminist theorising of relationality, and in particular with relations of caring. The importance of building and maintaining social ties is central to this understanding and to that of many of our interviewees. Finally, many peacebuilders in Delta State also share ideas present in the feminist literature about the need to include women in political processes, though there was disagreement about the extent and forms of such inclusion.

These various notions of peace are not incompatible; but the introduction of a gender lens brings to the fore conflicting understandings. Gender structured visions of peace lead to reproductions and contestations of gender divisions of labour and gender identities. The structuring logic of gender played a key role in the framing of peace as an absence of violence. It also led some peacebuilders to a priori assume that it is men who have the inclination to resort to violence, and therefore to prioritise male employment. It also functioned to reproduce the gendered distribution of and rights over natural resources. Even though many of our interviewees - particularly women's organisations-referred to economic injustices, built connections between violence and economic inequalities, and framed economic development as a prerequisite for peace, others did not consider the gendered dimensions of structural violence in their understandings of economic peace. This became evident in their focus on male employment and their disregard of gender discriminations in the governance of resources such as land ownership. Likewise, we have shown that even though many interviewees thought that women needed to be included in politics and peace processes, some NGO s explicitly instrumentalised women's inclusion/participation for peacebuilding purposes. In the vigilante group, understandings of appropriate gender roles led to a framing of women as 'weak' and unable to support the group's operations against crime.

Gender identities also limited more inclusive visions of peace. Relationality and relations of care, particularly between mothers and their children, 
anchored understandings of peace as harmonious living. The structuring logic of gender provided the script for constructing motherhood as the appropriate role for women. But the arguments around what it means to be 'a good woman' recognised that mothering requires skills and competence, and some of the NGO s interviewed sought to support the development of this feminine identity, encouraging performances of the 'good woman' by enhancing the power of mothers to teach their children how to act peacefully. While thus using gender as a resource for political change, they ended up forgoing an opportunity to generalise maternal thinking and practices beyond a feminine ghetto.

Our analysis, thus, shows that visions of peace are multiple and at times conflicting. They are often informed by gender logics, which shape the practices of building peace in Delta State, such as the ways in which women and their issues are included in or excluded from the processes of peacebuilding, the identities evoked, and the divisions of labour reproduced. Identifying and problematising visions of peace constitutes an important aspect of community struggles to transform violence, building caring ties, and promoting an understanding of gender equality that also takes women's empowerment as a goal in itself.

\section{References}

Ahearne, J. (2009) 'Neoliberal Economic Policies and Post-conflict Peace-building: A Help or Hindrance to Durable peace?', University of Leeds Polis Student Journal, 2, pp. 1-44, https://citeseerx.ist.psu.edu/viewdoc/download?doi=10.1.1.495.6411\&rep= rep1\&type $=\operatorname{pdf}($ accessed on 12 April 2021).

Allan, P. (2006) 'Measuring International Ethics: A Moral Scale of War, Peace, Justice, and Global Care', in A. Pierre and A. Keller (eds.) What is Just Peace? (Oxford: Oxford University Press).

Bodo, T., B.G. Gimah and K.J. Seomoni (2020) 'Illegal Oil Bunkering in the Nigerian Delta Region of Nigeria: A Challenge to Nigeria's Development', European Scientific Journal, 16(29), pp. 134-154, DOI:10.19044/esj.2020.v16n29p134.

Cohen, D.K. (2017) 'The Ties that Bind: How Armed Groups use Violence to Socialize Fighters',Journal of Peace Research, 54(5), pp. 701-714, DOI:10.1177/oo22343317713559. Cohen, D.K. (2016) Rape during Civil War (London: Cornell University Press).

Collier, P. (2009) 'The Market for Civil War', Foreign Policy, 2 November, https:// foreignpolicy.com/2009/11/o2/the-market-for-civil-war/ (accessed on 28 April 2021).

Cohen, D.K. (2013) 'Explaining Rape During Civil War: Cross-National Evidence (1980-2009)', American Political Science Review, 107(3), pp. 461-477, Dor: 10.1017/ Sooo3055413000221. 
Collier, P. and A. Hoeffler (2004) 'Greed and Grievance in Civil War', Oxford Economic Papers, 56, pp. 563-595, DoI: 10.1093/oep/gpfo64.

Costantino, R. (2012) 'Guatemaltecas Have Not Forgotten: From Victims of Sexual Violence to Architects of Empowerment in Guatemala', in C. Rittner and J.K. Roth (eds.) Rape: Weapon of War and Genocide (Minnesota: Paragon House).

Daigle, M. and H. Myrttinen (2018) 'Bringing Diverse Sexual Orientation and Gender Identity (SOGI) into Peacebuilding Policy and Practice', Gender \& Development, 26(1), pp. 103-120, DOI: 10.1080/13552074.2018.1429o91.

Drumond (2018) 'Sex, violence, and heteronormativity. Revisiting performances of sexual violence against men in former Yugoslavia', in M. Zalewski, P. Drumond, E. Prügl and M. Stern (eds) Sexual Violence Against Men in Global Politics (Routledge: London), DoI: 10.4324/9781315456492.

Duncanson, C. (2016) Gender and Peacebuilding (Hoboken: Wiley).

Ebiede, T.M. (2017) 'Beyond Rebellion: Uncaptured Dimensions of Violent Conflicts and the Implications for Peacebuilding in Nigeria's Niger Delta', African Security, 1O(1), pp. 25-46, DOI: 10.1080/19392206.2016.1270140.

Eriksson Baaz, M. and M. Stern (2013) Sexual Violence as a Weapon of War? Perceptions, Prescriptions, Problems in the Congo and Beyond (London and New York: Zed Books).

Eriksson Baaz, M. and M. Stern (2009) 'Why do Soldiers Rape? Masculinities, Violence and Sexuality in the Armed forces in the Congo (DRC)', International Studies Quarterly, 53, pp. 495-518, https://www.jstor.org/stable/27735106.

Forcey, L.R. (1991) 'Women as Peacemakers: Contested Terrain for Feminist Peace Studies', Peace \& Change, 16(4), pp. 331-354, Dor: 10.1111/j.1468-0130.1991.tboo674.x.

Galtung, J. (1969) 'Violence, Peace, and Peace Research', Journal of Peace Research, 6(3), pp. 167-191, DOI: 10.1177/oo22343369oo6oo3o1.

Galtung, J. (1964) 'An Editorial', Journal of Peace Research, 1(1), pp. 1-4, DOI: 10.1177/ oo2234336400100101.

Hudson V.M., B. Ballif-Spanvill, M. Caprioli and C.F. Emmett (2012), Sex and World Peace (Columbia University Press: New York).

Lederach, J.P. (2007) 'Keynote Speech: From Truce to Transformation-Live Issues V' (Belfast: Community Relations Commission).

Mac Ginty, R. (2014) ‘Everyday Peace: Bottom-up and Local Agency in Conflict-Affected Societies', Security Dialogue, 45(6), pp. 548-564, DoI: 10.1177/o967010614550899.

Mac Ginty, R. and O.P. Richmond (2013) 'The Local Turn in Peace Building: A Critical Agenda for Peace', Third World Quarterly, 34(5), pp. 763-783, DoI: 10.1080/ o1436597.2013.80075o.

Meger, S. (2011) 'Rape in Contemporary Warfare: The Role of Globalization in Wartime Sexual Violence', African Conflict and Peacebuilding Review, 1(1), pp. 100-132, DOI: 10.1353/acp.2011.0003. 
Meger, S. (2016) Rape Loot Pillage: The Political Economy of Sexual Violence in Armed Conflict ( New York: Oxford University Press), https://muse.jhu.edu/article/424034 (accessed on 12 April 2021).

Miall, H. (2007). Emergent Conflict and Peaceful Change (Basingstoke: Palgrave).

Mitchell, A. (2011) 'Quality/Control: International Peace Interventions and the Everyday', Review of International Studies, 37(4), pp. 1623-1645, DoI:10.1017/ So260210511000180.

Noddings, N. (2008) 'Caring and Peace Education', in Bajaj, M. (ed.) Encyclopedia of Peace Education (Information Age Publishing).

Oyewumi, O. (2003) 'Abiyamo: Theorizing African Motherhood', Jenda: A Journal of Culture and African Women Studies, 4(1), pp. 1-16.

Paczynska, A. (2016) 'Liberia Rising? Foreign Direct Investment, Persistent Inequalities and Political Tensions', Peacebuilding, 4(3), pp. 297-316, DOI: 10.1080/ 21647259.2016.1193938.

Paffenholz, T., N. Ross, S. Dixon, A. Schluchter and J. True (2016) 'Making Women Count-Not Just Counting Women: Assessing Women's Inclusion and Influence on Peace Negotiations. Geneva: Inclusive Peace and Transition Initiative' (Geneva: Inclusive Peace and Transition Initiative [The Graduate Institute of International and Development Studies] and UN Women), https://wps.unwomen. org/pdf/research/Making_Women_Count.pdf (accessed on 12 April 2021).

Peterson, J.H. (2014) Building a Peace Economy? Liberal Peacebuilding and the Development-Security Industry (Manchester: Manchester University Press).

PIND (Foundation for Partnership Initiatives in the Nigerian Delta) (2020) Niger Delta Annual Conflict Report, https://pindfoundation.org/niger-delta-annual-conflictreport-january-december-2020/ (accessed on 12 April 2021).

Prasch, A.M. (2015) 'Maternal Bodies in Militant Protest: Leymah Gbowee and the Rhetorical Agency of African Motherhood', Women's Studies in Communication, 38(2), pp. 187-205, DOI: 10.1080/07491409.2014.993105.

Prattern, D. (2008) 'Introduction. The Politics of Protection: Perspectives on Vigilantism in Nigeria', Africa:Journal of the International African Institute, 78(1), pp. 1-15, DOI: 10.3366/Eooo1972008000028.

Prügl, E. (2016) 'Neoliberalism with a Feminist Face: Crafting a New Hegemony at the WorldBank', FeministEconomics, 23(1), pp.30-53, DOI:10.108o/13545701.2016.1198043.

Reid-Cunningham, A. (2008) 'Rape as a Weapon of Genocide', Genocide Studies and Prevention: An International Journal, 3(3), DOI: 10.3138/gsp.3.3.279.

Rigual, C. (2018) 'Rethinking the Ontology of Peacebuilding: Gender, Spaces and the Limits of the Local Turn', Peacebuilding, 6(2), pp. 144-169, DoI: 10.1080/ 21647259.2018.1453640.

Ross, M.L. (1999) 'The Political Economy of the Resource Curse', World Politics, 51(2), pp. 297-322, https://www.jstor.org/stable/25054077. 
Ruddick, S. (1989) Maternal Thinking: Towards a Politics of Peace (Boston: Beacon Press).

Seifert, R. (1996) 'The Second Front: The Logic of Sexual Violence in Wars', Women's Studies International Forum, 19(1-2), pp. 35-43, DoI: 10.1016/o277-5395(95)ooo78-X. Serrano-Amaya, J.F. (2018) Homophobic Violence in Armed Conflict and Political Transition (London: Palgrave Macmillan).

True, J. and Y. Riveros-Morales (2019) 'Towards Inclusive Peace: Analysing Gendersensitive Peace Agreements 2000-2016', International Political Science Review, 40(1), pp. 23-40, DOI: 10.1177/01925121188086o8.

Vaittinen, T., A. Donahoe, R. Kunz, S. Bára Ómarsdóttir and S. Roohi (2019) 'Care as everyday peacebuilding', Peacebuilding, 7(2), pp. 194-209, DOI: 10.1080/ 21647259.2019.1588453.

Wood, E. (2018) 'Rape as a Practice of War: Toward a Typology of Political Violence', Politics and Society, 46(4), pp. 513-537, Dor: 10.1177/oo32329218773710.

Wood, E. (2009) 'Armed Groups and Sexual Violence: When is Wartime Rape Rare?', Politics and Society, 37(1), pp. 131-161, DOI: 10.1177/oo32329208329755.

Wood, E. (2006) Variation in Sexual Violence During War', Politics and Society, 34(3), pp. 307-342, DOI: 10.1177/oO32329206290426. 